This is the peer reviewed version of the following article: Navarro, María J, Francisco R López-Serrano, Lucía A Escudero-Colomar, and Francisco J Gea. 2020. "Cultivation Of Agaricus Bitorquis Mushroom As An Strategy For The Integrated Pest Management Of The Myceliophagous Mite Microdispus Lambi". Pest Management Science. Wiley. doi.org/10.1002/ps.5840, which has been published in final form at https://doi.org/10.1002/ps.5840. This article may be used for non-commercial purposes in accordance with Wiley Terms and Conditions for Use of Self-Archived Versions http://www.wileyauthors.com/self-archiving.

Document downloaded from: 


\section{Cultivation of Agaricus bitorquis mushroom as an strategy for the Integrated Pest}

\section{Management of the myceliophagous mite Microdispus lambi}

María J. Navarro ${ }^{\ddagger}$ Francisco R. López-Serrano ${ }^{\ddagger}$, Lucía A. Escudero-Colomar, Francisco J. Gea ${ }^{\ddagger}$

${ }^{\ddagger}$ Centro de Investigación, Experimentación y Servicios del Champiñón (CIES). 16220

Quintanar del Rey, Cuenca, Spain. Phone number: (+34)967496198. e-mail address:

mjnavarro.cies@dipucuenca.es; fjgea.cies@dipucuenca.es

¥ Departamento de Ciencia y Tecnología Agroforestal y Genética. Escuela Técnica

Superior de Ingenieros Agrónomos y de Montes (ETSIAM). Universidad de CastillaLa Mancha. 02071 Albacete, Spain. Fco.Lopez@uclm.es

*IRTA. Protecció Vegetal Sostenible (Entomologia). Estació Experimental Agricola

Mas Badia. 17134 La Tallada d'Empordà, Girona, Spain. adriana.escudero@irta.cat

Key words: Agaricus bisporus, mites, phoresis, diptera, Megaselia halterata

Running title: $A$. bitorquis crop as IPM of $M$. lambi

This article has been accepted for publication and undergone full peer review but has not been through the copyediting, typesetting, pagination and proofreading process which may lead to differences between this version and the Version of Record. Please cite this article as doi: $10.1002 /$ ps.5840 


\begin{abstract}
BACKGROUND: The phorid fly Megaselia halterata Winnertz (Diptera: Phoridae) is the principal vector of Microdispus lambi (Acari: Pygmephoroidea) in Spanish Agaricus bisporus Lange (Imbach) mushroom farms. This myceliophagous mite does not appear to be a pest in Agaricus bitorquis (Quél.) Sacc mushroom crops. This study explores the role of phorid flies as vectors of Microdispus lambi in Agaricus bitorquis mushroom crops.
\end{abstract}

RESULTS: The incidence of $M$. lambi in A. bitorquis growing substrates did not reach appreciable levels at any point during the growing cycle. The presence of phorid flies in 
A. bitorquis farms was normally higher than that in the case of Agaricus bisporus Lange (Imbach) species. The percentage of phorid vectors did not statistically differ between both Agaricus crops during infection periods. However, by the end of the crop, this percentage had increased only in A. bisporus crops, coinciding with a high incidence of mites in the substrate of this mushroom species; Megaselia halterata emerging from the mushroom substrate of $A$. bitorquis summer crops did not carry mites as they were absent from compost and casing.

CONCLUSION: M. halterata is a pest in Spanish A. bitorquis mushroom crops, meanwhile $M$. lambi, its phorectic mite, has shown not to be a pest of this species mushroom farms during the spring-summer growing season. A. bitorquis crops could potentially be used as an IPM measure to decrease the incidence and prevent the propagation of the myceliophagous mite $M$. lambi in A. bisporus mushroom growing farms.

Key words: Agaricus bisporus, mites, phoresis, diptera, Megaselia halterata, IPM

\section{INTRODUCTION}

Mushrooms are considered as a good source of proteins, vitamins, fats, carbohydrates, amino acids and minerals, as well as possessing important medicinal properties ${ }^{1}$. In recent years, the summer white button mushroom Agaricus bitorquis has attracted attention as a functional food, e.g. selenium-fortified food ${ }^{2}$, and as a source of new drugs, e.g. antitumor polysaccharides, or for its more general antimicrobial activities ${ }^{3-7}$. 
Despite slight phylogenetic differences, the biology of Agaricus bitorquis is little different from that of Agaricus bisporus (Lange) Imbach $^{8-11}$. Breeding studies, and even protoplast fusion techniques, have been used to develop interspecies fusants of $A$. bitorquis and A. bisporus, searching for strains with high yields and resistance to diseases and fungicides ${ }^{12-14}$. Both mushroom species require almost the same cultivation practices, although $A$. bitorquis prefers higher temperatures and $\mathrm{CO}_{2}$ levels. A. bitorquis is grown in a mesophilic temperature range of 20 to $30{ }^{\circ} \mathrm{C}$, making it a very important mushroom especially for tropical countries ${ }^{13,15-17}$. In Spain, its growing temperatures are considerably below those mentioned in the literature ${ }^{18-19}$, and the natural infection of A. bitorquis crops by pathogens such as Lecanicillium fungicola var. fungicola (Preuss) has been described ${ }^{20}$. Another important difference is that the individual growing stages within the $A$. bitorquis crop cycle are longer than those described for $A$. bisporus, with weekly yields (known as flushes) possible up to the $10^{\text {th }}$ week of cropping ${ }^{13}$.

The myceliophagous mite Microdispus lambi (Krczal) (Acari: Pygmephoroidea) was detected for the first time in Spain in the summer of 1996, when it caused substantial economic losses ${ }^{21}$. A study of some Spanish mushroom pests points to the phorid fly Megaselia halterata Winnertz (Diptera: Phoridae), the main mushroom fly in Spanish mushroom farms ${ }^{22-23}$, as the principal vector of M. lambi in Spanish mushroom farms. This is because of the high number of phorid flies, which are more abundant than sciarid flies (Lycoriella auripila Winnertz (Dipera: Sciaridae)) in Spanish farms ${ }^{22-23}$, and due to the high percentage of phorids that carry mites and the number of M. lambi that each phorid fly can carry ${ }^{25}$. 
Megaselia halterata is one of the most serious arthropod pest problems affecting the cultivation of mushroom throughout the world ${ }^{26-30}$. The preference of phorids for different cultivation materials ${ }^{27-28}$, different species of mushrooms ${ }^{31}$ or, even, different isolates of one particular mushroom species ${ }^{32}$ has been studied, and it has been found that they probably support the development of $M$. halterata in different ways.

The control of the myceliophagous mite pest is based on the control of phorid flies, and is usually based on strict hygiene practices in the growing facilities and the application of pesticides ${ }^{23}$. However, the appearance of pesticide resistance problems in flies, the presence of residues in carpophores ${ }^{24}$, and the reduction in the number of permitted active substances have led to the use of biological, biotechnological and cultural and physical measures, rather than chemical methods, in an attempt to promote the Integrated Pest Management (IPM) in mushroom crops $^{33-34}$.

The aim of this paper is to know if $M$. lambi and $M$. halterata are pests of $A$. bitorquis mushroom farms, and to find out more about the role of phorids as vectors of the myceliophagous mites in this species crops, in order to establish control measures of the pests.

\section{MATERIALS AND METHODS}

The study was carried out over two summers and one spring periods on six A. bitorquis and twelve A. bisporus growing farms in Castilla-La Mancha (Spain), with two crop cycles of $A$. bitorquis and four cycles of $A$. bisporus mushroom per period. Each crop was located in a growing room $\left(35 * 2.5 c^{*} 2 \mathrm{~m}\right)$ with a door for access at the front and a 
ventilation hole at the rear. Each crop was entirely grown in a single room and completed within 70 days (A. bisporus) or 85 days (A. bitorquis).

\subsection{Incidence of Microdispus lambi in mushroom farms}

A sampling calendar was established for each of the 6 A. bitorquis growing crops studied. Samples were collected at five time points: after incubation (approx. day 20), after the primordia had formed in the upper surface of the growing unit (induction, day 30 approx.), and after harvesting the first flush (F1, day 45 approx.), third flush (F3; day 65 approx.) and fifth flush (F5; day 85 approx.). The same five sampling time points were established for each of the $12 \mathrm{~A}$. bisporus crops, but the days after harvesting periods were slightly modified (after F1, day 41; after F3, day 56; after F5, day 70). A total of 30 samples were taken from each crop cycle (six samples per sampling day). To extract the mites, each sample was submitted to an extraction process (20 g) using Berlese-Tullgren funnels. The mites were collected in an ethanol-glycerine-water solution (6+1+3 by volume) and placed in Petri dishes, where they were identified and counted $^{35}$. The parameter defined for the study was the number of M. lambi per $120 \mathrm{~g}$ of sample.

\subsection{Incidence of the mushroom phorid Megaselia halterata in the farms}

Three double sided $(20 * 14 \mathrm{~cm})$ sticky yellow plates (Aragro S.A., Spain) were used to trap the adult flies in each farm. The sticky plates were removed weekly. Eight growing stages were established: incubation, casing, induction and the first (F1), second (F2), third (F3), fourth (F4) and fifth flushes (F5). Trapped diptera were identified by 
stereoscopic microscope and counted. The parameter defined for the study was the total number of adult phorid flies trapped per day, for each time point and each farm.

\subsection{Study of the phoretic role of $M$. halterata as vector of $M$. lambi}

For each farm, a black light lamp (60 cm, Philips TLD 18w/08, Holland), equipped with a plastic sheet treated with a contact insecticide, was installed under the ventilation hole in order to collect the flies. Each farm was visited weekly. On each sampling day a maximum of 48 flies was randomly collected in well-plates (IWAKI Glass, Japan) and taken to the laboratory, where flies were identified by binocular microscope (Nikon SMZ-2T, Japan) and mites that were phoretic on them were also identified and counted. The parameters defined for the study were the percentage of phorids carrying $M$. lambi mites, and the average load, defined as the number of $M$. lambi mites transported by each carrier phorid.

\section{Statistical analyses}

The study consisted in a full factorial experimental design with three factors (species of mushroom, season and growing stage) to evaluate their effects on different interest variables. A GLM ${ }^{36}$ was developed for each of the variables studied: (i) the presence of the myceliohagous mite Microdispus lambi in the growing substrates, (ii) the incidence of phorid M. halterata in the mushroom farms, (iii) the percentage of phorid vectors and (iv) the load that the phorids carried, evaluating in each of them the effects of the factors "species" (two levels: A. bisporus and A. bitorquis), "season" (three levels: summer1, spring and summer2) and "stage" (five-eight levels: incubation, casing, induction, F1, 
F2, F3, F4 and F5) as well as their interactions. In the case of M. lambi, a total of 90 observations were evaluated for each variable - as a consequence of our full factorial experiment design, consisting of 3 seasonal periods and 5 growth stages, with 4 replicates for $A$. bisporus and 2 replicates for $A$. bitorquis crops. In the case of $M$. halterata and its phoretic parameters, the number of observations increased to 144 , resulted of 3 seasonal periods and 8 growth stages, with 4 replicates for $A$. bisporus and 2 replicates for $A$. bitorquis crop. To test whether continuous variables fitted a normal distribution, data was examined using a normal probability plot, standardized skewness and kurtosis, and the Kolmogorov-Smirnov test. A natural logarithmic transformation was used to account some of the observed heterogeneity of variance in the raw data concerning the presence of mites and phorids. An SQRT transformation was used to account some of the observed heterogeneity of variance in the raw data of the percentage of phorids as vectors and load. The effect of the Agaricus species and each particular season and growing stage on the variables was tested using indicator variables (or dummy variables) in a multiple regression analysis ${ }^{37}$. These indicator variables (predictor variables) were the different species ( $\mathrm{k}-1$ indicator or dummy variables, $\mathrm{k}=2$ levels of species), the season ( $k-1$ indicator or dummy variables, $k=3$ levels of seasons) and the growing stages ( $\mathrm{k}-1$ indicator or dummy variables, $\mathrm{k}=5$ levels of growing stages for the presence of mites, and $k=8$ of the growing stages for the incidence of phorids and their phoretic parameters), and the interaction of all of them. The general linear statistic test (F-test) ${ }^{38}$ was used to test hypotheses about regression coefficients. All the 
statistical analyses were performed using the Statgraphics Centurion XV program (Statistical Graphics Corp., Princeton, NJ).

\section{RESULTS}

\subsection{Incidence of Microdispus lambi on the farms}

Extremely few myceliophagous mites were collected from the A. bitorquis crops regardless of the season or stage of the crop cycle (total number of mites captured per farm: 2-100 mites on A. bitorquis crops vs 2,915-6,210 mites on A. bisporus farms). The GLM developed to check the effect of the three factors ("species” "season” and "stage”) as well as their interactions on the studied variables showed "species" and "stage" factors and the interaction between them as being statistically significant $(\mathrm{p}<0.001, \mathrm{~F}-$ test) for the variable "presence of mites" in the growing substrates, meanwhile there was no significance for the "season" factor nor its interaction with the remaining factors ( $\mathrm{p}>$ 0.05, F-test) (Table 1).

The multiple regression analysis showed the stage "third flush" as being statistically significant ( $<<0.0001$, F-test), explained by the slightly increasing in the level of mites in both Agaricus species crops. Of note was the observation that "first flush”, “third flush” again and "fifth flush” stages appeared as statistically significant factors but only in the case of A. bisporus mushroom crops, clearly increasing the incidence of mites in the growing substrates of this mushroom species (Table 2). In other words, both mushroom species crops showed approximately the same level of infestation by mites until the beginning of the harvesting period. However, the high 
increase of the incidence of mites in growing substrates during the last flushes was only detected for A. bisporus crops (Figure 1a).

[Table 1]

\subsection{Incidence of mushroom phorid fly Megaselia halterata on the farms}

The average number of adult flies captured per trap and day in A. bitorquis mushroom farms was 115 phorids and 33 sciarids. The predominance of phorids over sciarid flies in this mushroom species crops was also registered.

The GLM developed to check the effect of the three factors ("species” "season" and "stage") as well as their interactions on the studied variables showed "species" and "stage” and the interaction between "species and season” to be statistically significant ( $<<0.001$, F-test) on the incidence of phorid flies, but there were no significance for "season" nor its interaction with the remaining factors ( $\mathrm{p}>0.05$, F-test) (Table 1). The multiple regression analysis (Table 2) showed all of the growing stages as statistically significant $(\mathrm{p}<0.0001, \mathrm{~F}$-test), regardless of the species of Agaricus, the levels of phorids decreasing in the case of "incubation" stage and increasing for all the others stages. Of note is that Agaricus bisporus factor was also statistically significant ( $\mathrm{p}<0.0001, \mathrm{~F}$-test), the incidence of phorid flies decreasing, in general terms, on those farms.

Summarizing, growing "stage" was the main factor for the incidence of phorid flies in mushroom farms. The "species” of Agaricus also was influential, but the incidence of $M$. halterata increased on $A$. bitorquis farms, probably due to the longer 
period of the growing stages in these crops, which allowed the appearance of the second generation of flies entirely developed inside the growing substrates.

[Table 2]

\subsection{Study of the phoretic role of $M$. halterata as vector of M. lambi}

The GLM developed to check the effect of the three factors ("species" "season" and "stage”) as well as their interactions on the studied variables showed "species” and "stage” factors and the interaction between those factors as statistically significant ( $\mathrm{p}<0.001$, F-test) on the percentage of phorid vectors, meanwhile there was no significance in "season" factor and the rest of interactions between them (Table 1). The multiple regression analysis (Table 2) showed “incubation” and “casing” stages as statistically significant ( $<<0.0001, \mathrm{~F}$-test), regardless of the species of Agaricus, the percentage of phorid vectors increasing in both stages, while "fourth flush" and "fifth flush” stages were also statistically significant, but only for A. bisporus crops in which the percentage of phorid vectors increased. That is, the percentage of phorid vectors was similar in both Agaricus crops during the incubation-induction periods (time considered as infection periods) and the three first flushes. However, at the end of the crop, this value had only increased in A. bisporus crops.

The GLM developed to check the effect of the three factors ("species" "season" and "stage") and of their interactions on the load of mites carried on each phorid vector showed "species" and "stage" and the interaction between them to be statistically significant ( $\mathrm{p}<0.001, \mathrm{~F}$-test), but there were no significance for "season" and the rest of the interactions (Table 1). The multiple regression analysis (Table 2) showed "Agaricus 
bisporus” to be statistically significant ( $\mathrm{p}<0.0001$, F-test), increasing the load. On the other hand, the "incubation" stage was also statistically significant, increasing the load, but not in A. bisporus crops. That is to say that the number of mites carried on each phorid vector was higher almost throughout the growth cycle of A. bisporus, except during the incubation stage when the value was lower for $A$. bisporus that for $A$. bitorquis crops.

[Figure 1]

\section{DISCUSSION}

Clift \& Toffolon (1981) demonstrated than the myceliophagous mite Microdispus lambi was capable of reproducing on A. bisporus as on A. bitorquis mycelium, although it could not sustain itself once the mycelium had completely colonised the compost ${ }^{39}$. Contrary to Agaricus bisporus mushroom crops $^{21}$, M. lambi appears not to be a pest on A. bitorquis mushroom farms in Spain. The incidence of myceliophagous mites in the growing substrates of summer mushrooms did not reach appreciable levels at any point during the crop cycle (Figure 1a). Both species of Agaricus show differences in their susceptibility to attack by pathogens, such as the fungi that cause diseases like " false truffle “ and “dry bubble»13,16,20. As regards flies, the lower incidence of mushroom sciarids in summer mushroom crops compared to that observed in A. bisporus farms has been established ${ }^{40}$, but it is not clear whether $A$. bitorquis is inherently less suitable as a host for L. agarici (synomysed with L. auripila) or whether a temperature effect is operating. The preference of Megaselia halterata for particular materials or species of mushroom has also been established ${ }^{27-28,31-32}$, but to the best of our knowledge, there 
have been no studies published on the incidence of this in A. bitorquis farms. It is possible that the absence of mites in A. bitorquis crops could be due to the low presence, in these farms, of the phorid flies, that are the main phoretic vectors for mites in A. bisporus farms ${ }^{25}$.

The results of the present paper point to an important presence of phorid flies on A. bitorquis farms, normally higher than on A. bisporus crops (Figure $1 \mathrm{~b})$. This might be due to the longer period of the growing stages, which would allow the second generation of flies to completely develop inside the growing substrates. That is to say, $M$. halterata is obviously a pest of $A$. bitorquis mushroom crops. The percentage of phorids carrying mites registered during infection periods (incubation-induction stages) was not statistically different between both Agaricus crops (Figure 1b), while the number of phoretic mites (load) was significantly higher in the incubation stage of $A$. bitorquis compared to A. bisporus (Figure 1c). In other words, A. bitorquis growing substrates had the same infestation by $M$. lambi as $A$. bisporus growing substrates. But this mite did not install itself as a pest in summer mushroom crops. The threshold temperature of development (female) for $M$. lambi has been established at $9{ }^{\circ} \mathrm{C}$, and it is known that all life stages of the mite die when exposed to a constant temperature of 35 ${ }^{\circ} \mathrm{C}$ for $24 \mathrm{~h}$, or $32{ }^{\circ} \mathrm{C}$ for 12 days ${ }^{41}$. However, the temperature registered inside the summer mushroom substrates did not reach these levels in either of the crops studied (data not shown). Whatever the case, the results of this study seem to contradict the possibility described in the literature ${ }^{39}$ that $M$. lambi can reproduce on A. bitorquis species. 
At the end of the crop cycle, the percentage of phorid vectors had only increased in A. bisporus crops, coinciding with the high incidence of mites in the substrates of this mushroom species. The phorids flies emerging from the summer mushroom crops did not carry mites on them due to the absence of mites in A. bitorquis mushroom substrates. After the cycle, new emerged flies would usually be attracted by the volatiles from the growing mycelium of new productive cycles. If those flies pick up mites they would probably infect nearby crops and contribute to the spread of $M$. lambi from infected crops to uninfected farms ${ }^{25}$. However, in A. bitorquis farms, the propagation of mites would be stopped. This difference between mushroom species, regarding the increment or reduction in the number of phorectic flies (in A. bisporus and A. bitorquis crops, respectively), explains the suitability of summer mushroom crops as a useful tool for the Integrated Pest Management (IPM) of Microdispus lambi, especially during outbreaks of mites in the production areas. However, it is necessary to continue the search for mechanisms to control the phorid fly to reduce the damage it causes and the consequences of its action as vector of other pests and diseases.

\section{REFERENCES}

1. Kakon AJ, Choudhury BK and Saha S, Mushroom is an ideal food supplement. $J$ Dhaka National Med Coll Hos 18:58-62 (2012).

2. Falandysz J, Selenium in Edible Mushrooms. J Environ Sci Health C Environ Carcinog Ecotoxicol Rev 26:256-299 (2008). 
3. Nandan CK, Patra P, Bhanja SK, Adhikari B, Sarkar R, Mandal S and Islam SS, Structural characterization of a water-soluble b- $(1 \rightarrow 6)$-linked D-glucan isolated from the hot water extract of an edible mushroom, Agaricus bitorquis. Carbohydr Res 343:3120-3122 (2008).

4. Beattie KD, Ulrich R, Grice ID, Uddin SJ, Blake TB, Wood KA, Steele J, Iu F, May TW and Tiralongo E, Ethanolic and aqueous extracts derived from Australian fungi inhibit cancer cell growth in vitro. Mycologia 103:458-465 (2011).

5. Ozturk M, Duru ME, Kivrak S, Mercan-Dogan N, Turkoglu A and Ozler MA, In vitro antioxidant, anticholinesterase and antimicrobial activity studies on three Agaricus species with fatty acid compositions and iron contents: A comparative study on the three most edible mushrooms. Food Chem Toxicol 49:1353-1360 (2011).

6. Rouf R, Tiralongo E, Krahl A, Maes, K, Spaan L, Wolf S, May TW and Tiralongo J, Comparative studie of hemagglutination and lectin activity in Australian medicinal mushrooms (higher basidomycetes). Int J Medicinal Mushr 13:493-504 (2011).

7. Glamočlija J, Stojković D, Nikolić M, Ćirić A, Reis FS, Barros L, Ferreira ICFR and Soković M, A comparative study on edible Agaricus mushrooms as functional foods. Food Funct 6:1900-1910 (2015).

8. Raper CA, Sexuality and the life-cycle of the edible wild Agaricus bitorquis. J Gen Microbiol 105:135-151 (1976).

9. Mitchell $\mathrm{AD}$ and Walter M, Species of Agaricus occurring in New Zealand. $N Z \mathrm{~J}$ Bot 37:715-725 (1999). 
10. Guan XJ, Xu L, Shao Y-C, Wang ZR, Chen F-S and Luo X-C, Differentiation of commercial strains of Agaricus species in China with inter-simple sequence repeat marker. World J Microbiol Biotechnol 24:1617-1622 (2008).

11. Colauto NB, Fermor TR, Eira AF and Linde GA, Pseudomonas putida stimulates primordia on Agaricus bitorquis. Curr Microbiol 72:482-488 (2016).

12. Pahil VS, Smith JF and Elliott TJ, The testing and improvement of high temperature, wild Agaricus strains for use in tropical and subtropical climates. Mushr Sci 13:589-599 (1991).

13. Yadav MC, Dhar BL and Verma RN, Breeding studies on development of high yielding and quality hybrids of Agaricus bitorquis. In: Science and Cultivation of Edible Fungi, ed by Van Griensven, Balkema, Rotterdam, ISBN 905809 1430, pp. 299-304 (2000).

14. Rana IS, Kanojiya A and Sandhu SS, Formation of interspecies fusants of Agaricus bisporus and Agaricus bitorquis mushroom by protoplast fusión. Indian J Microbiol 47:369-372 (2007).

15. Furlan SA, Virmond LJ, Miers DA, Bonatti M, Gern RMM and Jonas R, Mushroom strains able to grow at high temperatures and low pH values. World J Microbiol Biotechnol 13:689-692 (1997).

16. Ahlawat OP and Rai RD, Bacterial inoculants and their effect on the pinning, yield and false truffle disease incidence in Agaricus bitorquis. In: Science and Cultivation of Edible Fungi ed by Van Griensven, Balkema, Rotterdam, ISBN 90 5809 1430, pp. 695-699 (2000). 
17. Haroon-Ur-Rasheed, Saifullah S, Mohammad F and Nawab K, Effect of thermally composted culture media on the growth of hyphae from various parts of the basidiocarp of button mushroom, Agaricus bitorquis (Quelet) Sacc. Pak J Bot 44: 441-443 (2012).

18. Van Zaayen A and Gams W, Contribution to the taxonomy and pathogenicity of fungicolous Verticillium species II. Pathogenicity. Neth J Plant Path 88:143-154 (1982).

19. Nair NG and Macauley BJ, Dry bubble disease of Agaricus bisporus and A. bitorquis, and its control by prochloraz - manganese complex. New Zeal J Agr Res 30:107-116 (1987).

20. Gea FJ, Tello JC and Navarro MJ, Occurrence of Verticillium fungicola var. fungicola on Agaricus bitorquis mushroom crops in Spain. J Phytopathol 151:98100 (2003).

21. Navarro MJ, Gea FJ and Escudero A, Abundance and distribution of Microdispus lambi (Acari: Microdispidae) in Spanish mushroom crops. Exp App Acarol 50:309-316 (2010).

22. Navarro MJ, Escudero A, Ferragut F and Gea FJ, Evolution and seasonal abundance of phorid and sciarid flies in Spanish mushroom crops. In: Mushroom Biology and Mushroom Products. Proceedings of the fourth International Conference, ed by JE Sánchez, G Huerta \& E Montiel, Méjico, pp. 189-195 (2002). 
23. Navarro MJ, Gea FJ and Ferragut FJ, Biología y control del ácaro miceliófago Brennandania lambi (Krczal) en los cultivos de champiñón de Castilla-La Mancha, ed by MAPA, Madrid, 203 pp (2004).

24. Navarro MJ, Merino Ll and Gea FJ, Evaluation of residue risk and toxicity of different treatments with diazinon insecticide applied to mushroom crops. $J$ Environ Heal Sci B 52: 218-221 (2017).

25. Navarro MJ, López-Serrano FR, Escudero-Colomar LA and Gea FJ, Phoretic relationship between the myceliophagus mite Microdispus lambi (Acari: Microdispidae) and mushroom flies in Spanish crops. Ann Appl Biol 174:277-283 (2019).

26. Sandhu GS and Bhattal DS, Biology of phorid fly, Megaselia shandui Disney (Diptera: Phoridae) on temperate mushroom. In: Cultivating Edible Fungi, ed by Wuest, PJ, Royse, DJ and Beelman RB, Amsterdam: Elsevier, pp. 395-404 (1987).

27. Tibbles LL, Chandler D, Mead A, Jervis M and Boddy L, Evaluation of the behavioural response of the flies Megaselia halterata and Lycoriella castanescens to different mushroom cultivation materials. Entomol Exp Appl 116:73-81 (2005).

28. Jess S, Murchie AK and Bingham JFW, Potential sources of sciarid and phorid infestations and implications for centralised phases I and II mushroom compost production. Crop Prot 26:455-464 (2007).

29. Erler F, Polat E, Demir H, Cetinc H and Erdemira T, Control of the mushroom phorid fly, Megaselia halterata (Wood), with plant extracts. Pest Manag Sci 65:144-149 (2009). 
30. Shamshad A, The development of integrated pest management for the control of mushroom sciarid flies, Lycoriella ingenua (Dufour) and Bradysia ocellaris (Comstock) in cultivated mushrooms. Pest Manag Sci 66:1063-1074. (2010).

31. Joshi G, Mrig KK, Singh R and Singh S, Screening of oyster mushroom (Pleurotus species) against mushroom flies. Research on crops 12:222-225 (2011).

32. Smith JE, Challen MP, White PF, Edmondson RN and Chandler D, Differential effect of Agaricus host species on the population development of Megaselia halterata (Diptera: Phoridae). Bull Entomol Res 96:565-571 (2006).

33. Wang S, Di N, Chen X, Zhang F, Biondi A, Desneux N, Wang S, Life history and functional response to prey density of the flower bug Orius sauteri attacking the fungivorous sciarid fly Lycoriella pleuroti. J Pest Sci 92: 715-722 (2018).

34. Shamshad A, The development of integrated pest management for the control of mushroom sciarid flies, Lycoriella ingenua (Dufour) and Bradysia ocellaris (Comstock), in cultivated mushrooms. Pest Manag Sci 66:1063-1074 (2010).

35. Solomon ME, Tyroglyphid mites in stored products. Methods for the study of population density. Ann Appl Biol 32:71-75 (1945).

36. Gbur EE, Stroup WW, McCarter KS, Durham SL, Young LJ, Christman MC, West M and Kramer M, Analysis of generalized linear mixed models in the agricultural and natural resources sciences, ed by American Society of Agronomy, Soil Science Society of America, Crop Science Society of America. ISBN: 978-089118-182-8, 33 pp. DOI: 10.2134/2012.generalized-linear-mixed-models (2012). 
37. González-Ochoa A, López-Serrano FR and de las Heras J, Does post-fire forest management increase tree growth and cone production in Pinushalepensis? Forest Ecol Manag 188:235-247 (2004).

38. Neter J, Kutner MH, Nachtsheim CJ and Wasserman W, Applied Linear Statistical Models $4^{\text {th }}$, ed. by Irwin, Chicago (1996).

39. Clift AD and Toffolon RB, Biology, fungal host and economic significance of two pygmephorid mites (Acarina: Pygmephoridae) in cultivated mushroom, NSW, Australia. In: Mushroom Science XI, ed by Nair NG, Sidney, Australia, pp. 245253 (1981).

40. Clift AD and Toffolon RB, Insect and mites associated with mushroom cultivation on three commercial farms near Sidney, NSW, Australia. In: Mushroom Science XI, ed by Nair NG, Sidney, Australia, pp. 537-549 (1981).

41. Gao JR and Zou P, Biology, life table and host specificity of the mushroom pest, Brennandania lambi (Acari: Pygmephoroidea). Exp Appl Acarol 25:187-201 (2001) 
Table 1. Statistics of goodness of fit for the full model obtained by GLM for the response and predictive (factors) variables

\begin{tabular}{|c|c|c|c|c|c|c|}
\hline Variable $^{\dagger}$ & $\mathrm{R}^{2}$ & Factor & $\begin{array}{l}\text { Sum of } \\
\text { squares }\end{array}$ & d.f. & $\mathrm{F}$ & p-value \\
\hline \multirow{9}{*}{$\begin{array}{l}\text { Presence of mites } \\
\text { (mites/120 g) }\end{array}$} & \multirow{9}{*}{75.70} & Full model & 541.95 & 29 & 6.44 & 0.0000 \\
\hline & & Species & 74.71 & 1 & 25.76 & 0.0000 \\
\hline & & Season & 1.00 & 2 & 0.17 & 0.8416 \\
\hline & & Stage & 209.37 & 4 & 18.05 & 0.0000 \\
\hline & & Species*Season & 15.03 & 2 & 2.59 & 0.0832 \\
\hline & & Species*Stage & 87.86 & 4 & 7.57 & 0.0001 \\
\hline & & Season*Stage & 11.57 & 8 & 0.50 & 0.8523 \\
\hline & & Species*Season*Stage & 15.17 & 8 & 0.65 & 0.7293 \\
\hline & & Residual & 173.99 & 60 & & \\
\hline \multirow{9}{*}{$\begin{array}{l}\text { Incidence of } \\
\text { phorids } \\
\text { (adults/day) }\end{array}$} & \multirow[t]{9}{*}{69.07} & Full model & 317.48 & 47 & 4.47 & 0.0000 \\
\hline & & Species & 51.67 & 1 & 34.15 & 0.0000 \\
\hline & & Season & 1.62 & 2 & 0.53 & 0.5877 \\
\hline & & Stage & 180.39 & 7 & 17.03 & 0.0000 \\
\hline & & Species*Season & 25.58 & 2 & 8.46 & 0.0004 \\
\hline & & Species*Stage & 17.35 & 7 & 1.64 & 0.1342 \\
\hline & & Season*Stage & 7.85 & 14 & 0.37 & 0.9800 \\
\hline & & Species*Season*Stage & 7.69 & 14 & 0.36 & 0.9819 \\
\hline & & Residual & 142.20 & 94 & & \\
\hline \multirow{9}{*}{$\begin{array}{l}\text { Phorids as } \\
\text { Vectors } \\
(\%)\end{array}$} & \multirow[t]{9}{*}{55.58} & Full model & 523.73 & 47 & 4.00 & 0.0000 \\
\hline & & Species & 131.06 & 1 & 47.04 & 0.0000 \\
\hline & & Season & 3.06 & 2 & 0.55 & 0.5793 \\
\hline & & Stage & 143.59 & 7 & 7.36 & 0.0000 \\
\hline & & Species*Season & 18.86 & 2 & 3.39 & 0.0381 \\
\hline & & Species*Stage & 83.21 & 7 & 4.27 & 0.0004 \\
\hline & & Season*Stage & 47.58 & 14 & 1.22 & 0.2748 \\
\hline & & Species*Season*Stage & 26.43 & 14 & 0.68 & 0.7905 \\
\hline & & Residual & 256.32 & 92 & & \\
\hline \multirow{7}{*}{$\begin{array}{l}\text { Load } \\
\text { (mites/vector) }\end{array}$} & \multirow[t]{7}{*}{51.77} & Full model & 30.52 & 47 & 2.12 & 0.0010 \\
\hline & & Species & 6.69 & 1 & 21.89 & 0.0000 \\
\hline & & Season & 1.04 & 2 & 1.69 & 0.1894 \\
\hline & & Stage & 8.60 & 7 & 4.02 & 0.0007 \\
\hline & & Species*Season & 1.29 & 2 & 2.11 & 0.1271 \\
\hline & & Species*Stage & 5.02 & 7 & 2.34 & 0.0300 \\
\hline & & Season*Stage & 5.91 & 14 & 1.38 & 0.1783 \\
\hline
\end{tabular}


${ }^{\dagger}$ A natural logarithmic transformation of data concerning the presence of mites and incidence of phorids was used. An SQRT transformation of data concerning the percentage of phorids as vectors and load was used. 
Table 2. Regression coefficients for the predictor factors (k-1 dummy variables, being $\mathrm{k}$ the $\mathrm{n}^{\mathrm{o}}$ of levels for each factor) of the presence of mites, incidence of phorids, percentage of phorids as vectors and load of mites on each phorid vector and statistics for goodness of fit*

\begin{tabular}{|c|c|c|c|c|c|}
\hline & & $\begin{array}{c}\text { Presence } \\
\text { of mites } \\
\text { (mites/120g) }\end{array}$ & $\begin{array}{c}\text { Incidence } \\
\text { of phorids } \\
\text { (adults/day) }\end{array}$ & $\begin{array}{l}\text { Phorids as } \\
\text { vectors } \\
\text { (\%) }\end{array}$ & $\begin{array}{c}\text { Load } \\
\text { (mites/vector) }\end{array}$ \\
\hline Factors & Dummy variables & \multicolumn{4}{|c|}{ Coefficients $^{\dagger}$} \\
\hline & Constant & 1.31 & 202.23 & 5.72 & 0.70 \\
\hline Species & Agaricus bisporus & & -282.52 & & 1.43 \\
\hline Growth & Incubation & & -22.39 & 15.29 & 2.99 \\
\hline stage & Casing & & & 15.07 & \\
\hline \multirow{11}{*}{ Interaction } & First flush & & 153.94 & & \\
\hline & Second flush & & 286.44 & & \\
\hline & Third flush & 27.64 & 324.64 & & \\
\hline & Fourth flush & & 346.79 & & \\
\hline & Fifth flush & & 172.45 & & \\
\hline & (A. bisporus)*(Incubation) & & & & -2.99 \\
\hline & (A. bisporus)*(First flush) & 54.97 & & & \\
\hline & (A. bisporus)*(Third flush) & 477.45 & & & \\
\hline & (A. bisporus)*(Fourth flush) & & & 24.75 & \\
\hline & (A. bisporus)*(Fifth flush) & 3908.43 & & 31.42 & \\
\hline & (A. bisporus)*(Spring) & & 76.58 & & \\
\hline $\mathrm{n}$ & & 90 & $142^{\ddagger}$ & $140^{\ddagger}$ & $141^{\ddagger}$ \\
\hline $\mathrm{F}$ & & 47.95 & 23.11 & 21.70 & 13.52 \\
\hline $\mathrm{P}$ & & $<0.001$ & $<0.001$ & $<0.001$ & $<0.001$ \\
\hline $\mathrm{R}^{2}$ & & 69.29 & 58.16 & 39.14 & 22.84 \\
\hline SEE & & 1.61 & 1.20 & 1.88 & 0.58 \\
\hline
\end{tabular}

*All coefficients shown are significant at $\mathrm{P}<0.05$. Empty cells means that the coefficients are not significant $(\mathrm{P}>0.05)$. 
${ }^{\dagger}$ The response variables were not LOG or SQRT transformed.

₹There were between 2 to 4 missing data for these interest variables 


\section{Figure legends}

Figure 1. a) Progression of the presence of M. lambi (mites/120 g of substrate sample) in Agaricus bisporus and A. bitorquis crops. b) Progression of the incidence of $M$. halterata (total adults captured per day) and of phorids as vectors of M. lambi mites (\%) in the different periods of the growth cycle in both mushroom species. c) Progression of the load (number of mites carried by each phorid vector) in the different periods of the growth cycle in both mushroom species.

${ }^{\dagger}$ F1: first flush; F2: second flush; F3: third flush; F4: fourth flush; F5: fifth flush 

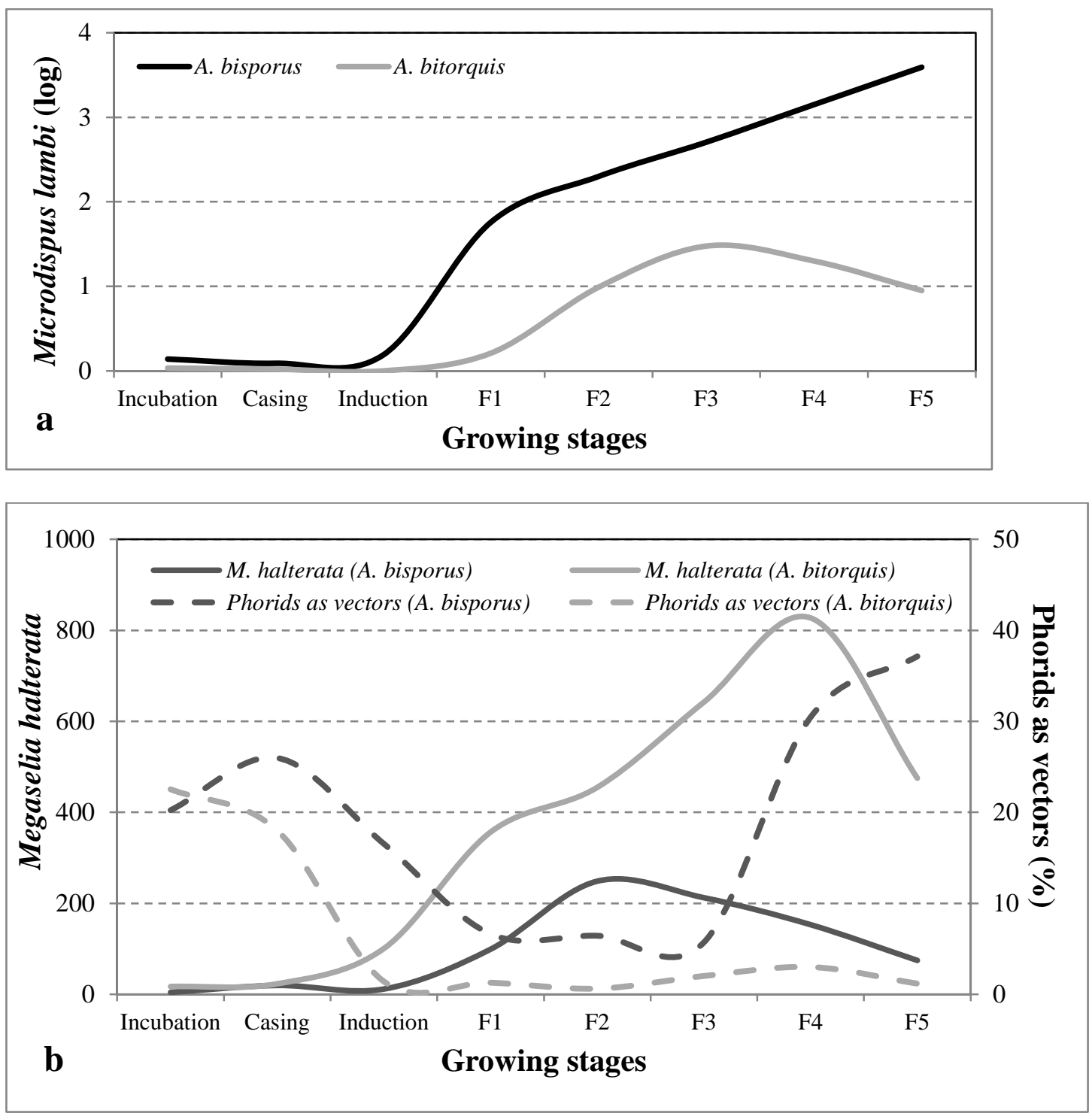


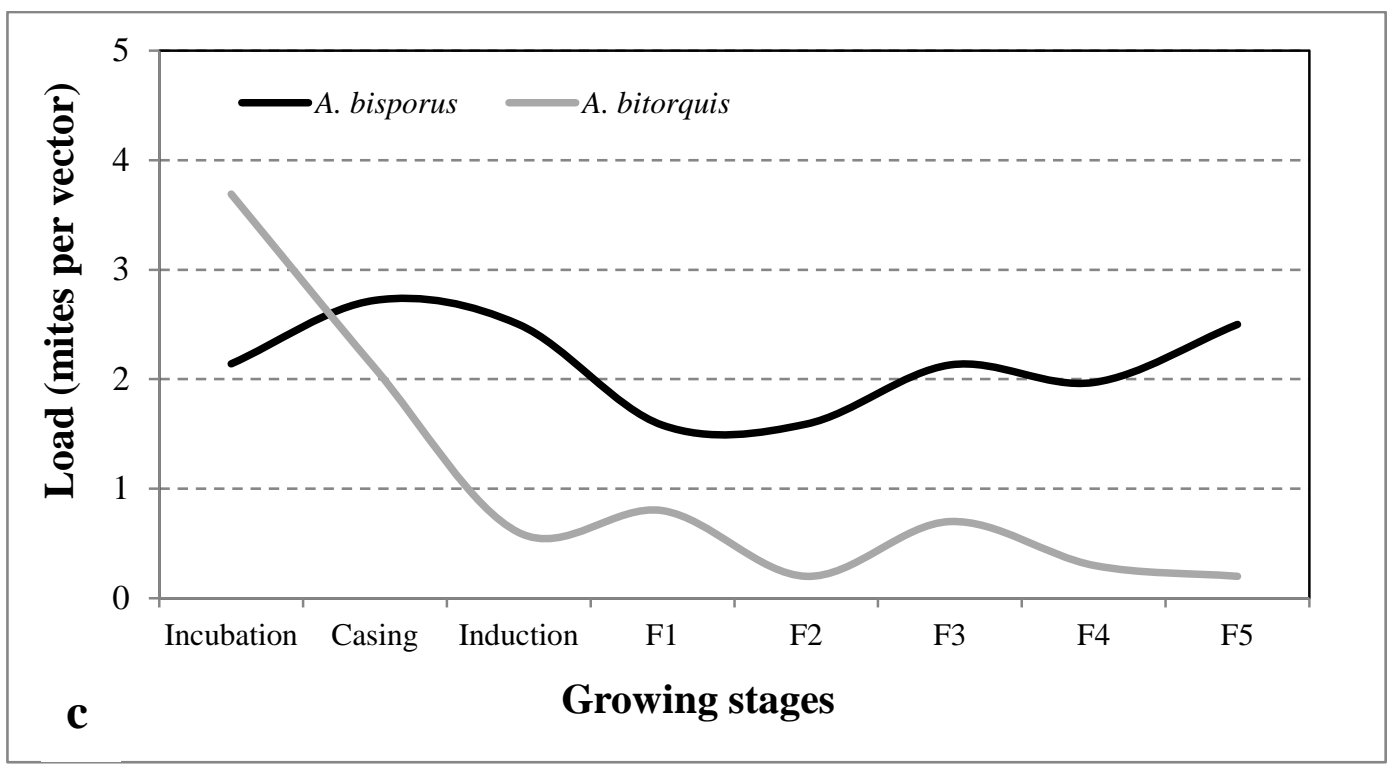

Figure 1 